\title{
Effects of micronutrient and spacing on growth and chlorophyll content of rice
}

\author{
Md. Dhin Islam*, Md.Yunus Miah, Mohammed Zia Uddin Kamal and Nishat
}

Farhana

\author{
Department of Soil Science, Bangabandhu Sheikh Mujibur Rahman Agricultural University, Gazipur-1706 \\ *Corresponding author: dhinislam@bsmrau.edu.bd
}

\begin{abstract}
An experiment was carried out at the research field of the Bangabandhu Sheikh Mujibur Rahman Agricultural University (BSMRAU).There were four nutrient treatments i.e., $E_{1}=N P K S$ recommended dose; $E_{2}=$ $N P K S+Z n 5 K g h a^{-1 ;} E_{3}=N P K S+Z n\left(5 K g h a^{-1}\right)+B(3$ $\left.K g h a^{-1}\right) E_{4}=N P K S+Z n\left(5 K g h a^{-1}\right)+B\left(3 K g h a^{-1}\right)+M o$ $\left(2 \mathrm{Kg} \mathrm{ha}^{-1}\right)$ and three spacing $S_{1}=20 \times 10 \mathrm{~cm}^{2} ; S_{2}=20 \times 15$ $\mathrm{cm}^{2}$ and $S_{3}=20 \times 20 \mathrm{~cm}^{2}$.Micronutrient and spacing combined had a distinct positive response in crop growth attributes and chlorophyll content of rice. The tallest plant height $(147.0 \mathrm{~cm})$ and root length $(13.50 \mathrm{~cm})$ highest panicle length $(22.56 \mathrm{~cm})$ was attained in the treatment $E_{2} S_{3}$ but the maximum tillers per hill (14.95) and effective panicle per hill (14.17) were recorded in treatment $E_{2} S_{2}$. Physiological parameter i.e., LAI, CGR, RGR, NAR, total chlorophyll content of rice also responded significantly and the appropriate combination was $E_{4} S_{2}$ treatment. Based on vegetative growth, physiological parameters and yield attributes the treatment combination $E_{4} S_{2}$ showed the best performance.
\end{abstract}

Keywords-Growth, chlorophyll, yield attributes and nutrients.

\section{INTRODUCTION}

Rice is the main food for the people of Bangladesh. Bangladesh is the 4th largest country in As ia with respect to rice production (BBS, 2004). It occupies $74 \%$ of the total cropped area, accounts for $70 \%$ of the value of crop output and contributes $20 \%$ to GDP (BBS, 2001). The average yield of rice in Bangladesh is around 2.74 tons per hectare (Anon, 2007) which is so lower than the world average of 4.25 tons per hectare. Peoples of Bangladesh have been facing shortage of rice yield for a long time. The horizontal expansion of rice area in the country is not possible due to increasing population pressure. Khan et al.(1999) reported thatimproper use of fertilizers and no use of micronutrients are limiting factors towards the higher rice yield.
Micronutrients statuses have been decreasing day by day and finally fertility status of Bangladesh soils become declining. Micronutrients play a vital role in the yield improvement (Rehm and Sims, 2006). Micronutrients deficiency is widespread in many Asian countries due to the calcareous nature of soils, high $\mathrm{pH}$, low organic matter, salt stress, prolonged drought, high bicarbonate contents in irrigation water and imbalanced application of NPK fertilizers. Micronutrient deficiency has become a major constraint for crop growth. Micronutrients help in chlorophyll formation (Reddy, 2004). Farmers of Bangladesh are habituated with the use of macro-nutrients for crop production. Kumar et al.(2002) stated that an optimum plant density is an important factor to achieve better growth of different rice varieties. Hamidulet al.(2002) rported thatthe growth and yield of rice plant is known to be affected quantitatively and qualitatively by plant spacing. So, the only option left to increase rice production is use of improved varieties and optimum spacing. Research on the use of micronutrients and spacing in increasing rice production is limited in Bangladesh.So due to lack of proper information on spacing the farmers are not getting proper yield. Considering the above mentioned facts, the present study was designed to ascertain - the combined effect of different micronutrient in presence of $\mathrm{N}, \mathrm{P}, \mathrm{K}, \mathrm{S}$ and spacing on growth of rice, to find out suitable micronutrient combination along with $\mathrm{N}, \mathrm{P}, \mathrm{K}, \mathrm{S}$ and spacing for rice production.

\section{MATERIALS AND METHODS}

An experiment was conducted at the research field of the Bangabandhu Sheikh Mujibur Rahman Agricultural University (BSMRAU), Gazipur. Soil of this experimental site was a silty clay loam under the Salna series of Shallow Red Brown Terrace.The experimental design was split plot having three replications. Experimental variables were consisted different combination of three micronutrients 
along with $\mathrm{N}, \mathrm{P}, \mathrm{K}$ and $\mathrm{S}$ arranged as main plots and three spacing as sub-plots for rice production. Micronutrients and spacing were arranged as follows -

Micronutrient treatments (Main Plot)

$\mathrm{E}_{1}=\mathrm{NPKS}$ recommended dose, $\mathrm{E}_{2}=\mathrm{NPKS}+\mathrm{Zn} 5 \mathrm{Kg} \mathrm{ha}^{-1}$, $\mathrm{E}_{3}=\mathrm{NPKS}+\mathrm{Zn}\left(5 \mathrm{Kg} \mathrm{ha}^{-1}\right)+\mathrm{B}\left(3 \mathrm{Kg} \mathrm{ha}^{-1}\right), \mathrm{E}_{4}=\mathrm{NPKS}+$ $\mathrm{Zn}\left(5 \mathrm{Kg} \mathrm{ha}^{-1}\right)+\mathrm{B}\left(3 \mathrm{Kg} \mathrm{ha}^{-1}\right)+\mathrm{Mo}\left(2 \mathrm{Kg} \mathrm{ha}^{-1}\right)$

Spacing treatments (Sub- Plot)

$\mathrm{S}_{1}=20 \times 10 \mathrm{~cm}^{2}, \mathrm{~S}_{2}=20 \times 15 \mathrm{~cm}^{2}$ and $\mathrm{S}_{3}=20 \times 20 \mathrm{~cm}^{2}$

A blanket dose of $65 \mathrm{~kg} \mathrm{~N}^{-1}{ }^{-1}$ as Urea, $7 \mathrm{~kg} \mathrm{P} \mathrm{ha}^{-1}$ from TSP, $28 \mathrm{~kg} \mathrm{~K} \mathrm{ha}^{-1}$ as MP and $8 \mathrm{~kg} \mathrm{~S} / \mathrm{ha}$ as Gypsum were applied to each treatment. All fertilizers applied as base dose except $\mathrm{N}$ fertilizer and $\mathrm{N}$ fertilizer applied as installments.Five hills per plot were selected randomly in the net plot and tagged for recording observations at four stages (30th, 60th, 90th day after transplanting and at harvest).For computing leaf area, numbers of tillers per hill were counted. The length and maximum width of each leaf on the middle tiller was measured and leaf area of each leaf was computed as follows.

Leaf area per hill $(\mathrm{sq} . \mathrm{cm})=$ Total leaf area of middle tiller $\times$ total number of tillers per hill

It was recorded for five hills separately and averaged to get leaf area per hill.

This physiological growth parameter was computed by using the following formulae-

LAI $=$ Leaf area of plant $/$ Land area covered by the plant.

CGR $\left(\mathrm{g} \mathrm{m}^{-2} \mathrm{day}^{-1}\right)=\mathrm{W}_{2}-\mathrm{W}_{1} / \mathrm{T}_{2}-\mathrm{T}_{1} \mathrm{X} 1 / \mathrm{GA}$

Where $\mathrm{W}_{1}=$ Dry weight at time $\mathrm{T}_{1}, \mathrm{~W}_{2}=$ Dry matter at time $\mathrm{T}_{2}, \mathrm{~T}_{2}-\mathrm{T}_{1}=$ Time interval between second and first measurement, $\mathrm{GA}=$ ground area of sample.

RGR $\left(\mathrm{g} \mathrm{g}^{-1}\right.$ day $\left.^{-1}\right)=\ln \mathrm{W}_{2}-\ln \mathrm{W}_{1} / \mathrm{T}_{2}-\mathrm{T}_{1}$

NAR $\left(m g m^{-2}\right.$ day $\left.^{-1}\right)=\left(\mathrm{W}_{2}-\mathrm{W}_{1}\right) /\left(\mathrm{T}_{2}-\mathrm{T}_{1}\right) \mathrm{X}\left(\ln \mathrm{LA}_{2}-\right.$ $\left.\mathrm{LA}_{1}\right) /\left(\mathrm{LA}_{2}-\mathrm{LA}_{1}\right)$

Where, $\ln =$ natural logarithm, $\mathrm{W}_{1}=$ Dry weight at time $\mathrm{T}_{1}$, $\mathrm{W}_{2}=$ Dry weight at time $\mathrm{T}_{2}, \mathrm{LA}_{1}=$ Leaf area at time $\mathrm{T}_{1}, \mathrm{LA}_{2}$ $=$ Leaf area at time $\mathrm{T}_{2},\left(\mathrm{~T}_{2}-\mathrm{T}_{1}\right)=$ Time interval between second and first measurement.

\section{RESULTS AND DISCUSSION}

Combined effects of different Micronutrient and spacing on rice have been tested which deals with the presentation of the experimental results along with their interpretation and discussion.

\section{Plant height}

Plant height indicates the influence of various nutrients on plant metabolism. The plant height of rice was significantly unaffected due to the application of different treatment combinations (Table 1).However; it was found that application of micronutrient along with macronutrient increased the plant height over macronutrients when applied separately. But maximum plant height $(147.0 \mathrm{~cm})$ was obtained in $\mathrm{E}_{2} \mathrm{~S}_{3}$. These results were statistically similar with the treatment $\mathrm{E}_{4} \mathrm{~S}_{3}$ (Table 1). The lowest plant height was recorded for only macronutrients application for all spacing. The increase in plant height in response to combined application of macro and micro nutrients along with different spacing is might be due to enhanced availability of macro nutrients as well as micro nutrients. These results are supported by the findings of Islam et al. (2010) who reported that the use of secondary and micronutrients maximized the plant growth and yield of $\mathrm{T}$. aman.

\section{Root length}

Applications of micronutrients along with macronutrientsand spacing had significant effect on the root length of rice (Table 1). The maximum root length (13.50 $\mathrm{cm})$ was obtained from the treatment $\mathrm{E}_{2} \mathrm{~S}_{3}$.The lowest root lengthmaintained by the application of macronutrient only in all spacing. This result was very close with the finding of Alamet al. (2010).

\section{Tiller number per hill}

Number of tillers per plant or per unit area is the most important component of yield. More the number of tillers, especially fertile tillers, the more will be the yield. Tillering capacity of a plant depends on the genotype and environment. The data pertaining to number of tillers revealed that micronutrients alone with macro nutrients and spacing had positive effect on number of tillers (Table 1). Among various treatments, the treatment $\mathrm{E}_{2} \mathrm{~S}_{2}$ produced the maximum number of tillers per hill (14.95) which was followed by the treatment $\mathrm{E}_{3} \mathrm{~S}_{1}$ (14.83).The minimum number of tillers was recorded in solely macronutrient application among the three spacing.So, these finding suggests that micronutrients had a positive influence on the increase of tillering number of rice (Sohelet al. 2009).

\section{Panicle number per hill}

The panicle number per hill was appreciably increased due to addition of micronutrients along with macronutrients and variation of spacing (Table 1). The maximum panicle (14.17) was recorded $\mathrm{inE}_{2} \mathrm{~S}_{2}$ treatment which was statistically similar with all other treatments except $E_{1} S_{3}$. However, the lowest panicle per hill (10.17) was recorded in $E_{1} S_{3}$.Rahman et al., (2008) found that application of $S$ and $\mathrm{Zn}$ had a significant impact on the panicle number of rice.

Panicle length

Panicle length responded significantly to micronutrients 
along with macronutrients and variation of spacing (Table 1). Among different treatments, the treatment $E_{2} S_{3}$ produced the highest panicle length $(22.56 \mathrm{~cm})$ which was statistically similar with the second highest treatment $\mathrm{E}_{2} \mathrm{~S}_{2}$ (22.14 $\mathrm{cm})$. The lowest panicle length $(16.53 \mathrm{~cm})$ was observed in the treatment $\mathrm{E}_{1} \mathrm{~S}_{1}$. Rahman et al., (2008) found that the treatment containing $100 \%$ of the recommended dose of $\mathrm{S}$ and $\mathrm{Zn}$ produced the highest panicle length and the control did the lowest.

\section{Number of grains panicle ${ }^{-1}$}

One of the basic yield components of rice is the number of grains penicle ${ }^{-1}$ which is affected by various factors including balanced nutrition. As shown in Table 1, micronutrients application along with basal dose of NPKS and spacing substantially improved the number of grains penicle $^{-1}$ in rice. Maximum number of grains per panicle (98.70) was produced in the treatment $\mathrm{E}_{4} \mathrm{~S}_{3}$ which was statistically similar with $\mathrm{E}_{2} \mathrm{~S}_{2}$ and $\mathrm{E}_{2} \mathrm{~S}_{3}$ with 97.50 and 95.85 grains penicle ${ }^{-1}$. Since micronutrient is responsible for the translocation of food materials in plants therefore it played vital role in grain setting as well as higher number of grains in rice. Present results are in line with Uddin et al. (2008) who obtained higher number of grains by the application of boron@2 kg ha-1. Minimum number of grains (52.40)was recorded in treatment $E_{1} S_{1}$. Similar finding was reported by the Hamid et al., (2011) that highest plant spacing gave the maximu $m$ number of grain per panicle.

\section{Filled grain panicle ${ }^{-1}$}

Filled grain per panicle of rice was highly accelerated by the micronutrients application along with basal dose of macronutrients and spacing (Table 1). Among different treatments, the treatment $\mathrm{E}_{2} \mathrm{~S}_{2}$ was produced the maximum filled grain per panicle (87.62) which was statistically similar with $\mathrm{E}_{2} \mathrm{~S}_{3}$ (87.05) and $\mathrm{E}_{4} \mathrm{~S}_{3}$ (85.43). The minimum grain per panicle (45.15) was recorded in the treatment $\mathrm{E}_{1} \mathrm{~S}_{1}$. This results agreed with the finding of Nadimet al., (2011) that with application of micronutrient along with basal dose of macronutrient provide the maximum grain number per panicle.

\section{0-grain weight $(\mathrm{g})$}

The data presented in Table 1 revealed that micronutrients application and spacing had significant effect on the grain weight. Maximum 1000 grain weight $(12.07 \mathrm{~g})$ was recorded in the treatment $\mathrm{E}_{2} \mathrm{~S}_{2}$ which was statistically similar at par $(11.37 \mathrm{~g})$ and $(11.17 \mathrm{~g})$ with grain weight obtained in $\mathrm{E}_{2} \mathrm{~S}_{1}$ and $\mathrm{E}_{2} \mathrm{~S}_{3}$ treatment respectively. The minimum grain weight $(10.12 \mathrm{~g})$ was recorded in $\mathrm{E}_{1} \mathrm{~S}_{1}$ treatment. This might be due to zinc and proper spacing enhanced accumulation of assimilates in the grains, which resulted in heavier grains of rice.

Table.1: Effect of micronutrient and spacing on Yield attributes of rice.

\begin{tabular}{|l|l|l|l|l|l|l|l|l|}
\hline Treatment & $\begin{array}{l}\text { Plant } \\
\text { height } \\
(\mathrm{cm})\end{array}$ & $\begin{array}{l}\text { Root length } \\
(\mathrm{cm})\end{array}$ & $\begin{array}{l}\text { Tiller } \\
\text { No./ hill }\end{array}$ & $\begin{array}{l}\text { Panicle } \\
\text { No./hill }\end{array}$ & $\begin{array}{l}\text { Panicle } \\
\text { length }(\mathrm{cm})\end{array}$ & Kernel/plant & $\begin{array}{l}\text { Filled } \\
\text { kernel /plant }\end{array}$ & $\begin{array}{l}1000 \text { seed } \\
\text { weight }(\mathrm{g})\end{array}$ \\
\hline $\mathrm{E}_{1} \mathrm{~S}_{1}$ & 131.5 & $11.17 \mathrm{bc}$ & 11.17 & $10.33 \mathrm{ab}$ & $16.53 \mathrm{~d}$ & $52.40 \mathrm{~cd}$ & $45.15 \mathrm{~d}$ & $10.12 \mathrm{~b}$ \\
\hline $\mathrm{E}_{2} \mathrm{~S}_{1}$ & 135.7 & $12.00 \mathrm{abc}$ & 12.33 & $11.83 \mathrm{ab}$ & $18.30 \mathrm{bcd}$ & $65.15 \mathrm{bcd}$ & $55.23 \mathrm{bcd}$ & $11.37 \mathrm{ab}$ \\
\hline $\mathrm{E}_{3} \mathrm{~S}_{1}$ & 133.8 & $12.00 \mathrm{abc}$ & 14.83 & $13.33 \mathrm{ab}$ & $21.24 \mathrm{ab}$ & $77.85 \mathrm{abc}$ & $63.90 \mathrm{abc}$ & $10.28 \mathrm{~b}$ \\
\hline $\mathrm{E}_{4} \mathrm{~S}_{1}$ & 134.2 & $11.83 \mathrm{bc}$ & 14.17 & $12.67 \mathrm{ab}$ & $17.53 \mathrm{~cd}$ & $65.36 \mathrm{bcd}$ & $55.65 \mathrm{bcd}$ & $11.62 \mathrm{ab}$ \\
\hline $\mathrm{E}_{1} \mathrm{~S}_{2}$ & 131.7 & $10.83 \mathrm{bc}$ & 12.83 & $12.17 \mathrm{ab}$ & $17.63 \mathrm{~cd}$ & $62.90 \mathrm{~cd}$ & $46.85 \mathrm{~cd}$ & $10.27 \mathrm{~b}$ \\
\hline $\mathrm{E}_{2} \mathrm{~S}_{2}$ & 136.3 & $12.17 \mathrm{ab}$ & 14.95 & $14.17 \mathrm{a}$ & $22.14 \mathrm{a}$ & $97.50 \mathrm{a}$ & $87.62 \mathrm{a}$ & $12.07 \mathrm{a}$ \\
\hline $\mathrm{E}_{3} \mathrm{~S}_{2}$ & 140.2 & $11.83 \mathrm{abc}$ & 13.50 & $12.67 \mathrm{ab}$ & $19.71 \mathrm{abcd}$ & $76.45 \mathrm{abc}$ & $64.73 \mathrm{abc}$ & $10.97 \mathrm{ab}$ \\
\hline $\mathrm{E}_{4} \mathrm{~S}_{2}$ & 139.8 & $12.00 \mathrm{abc}$ & 13.17 & $12.83 \mathrm{ab}$ & $18.62 \mathrm{bcd}$ & $88.40 \mathrm{ab}$ & $68.12 \mathrm{abc}$ & $10.88 \mathrm{ab}$ \\
\hline $\mathrm{E}_{1} \mathrm{~S}_{3}$ & 133.5 & $10.83 \mathrm{bc}$ & 10.67 & $10.17 \mathrm{~b}$ & $19.46 \mathrm{abcd}$ & $69.00 \mathrm{bcd}$ & $58.72 \mathrm{bc}$ & $10.03 \mathrm{ab}$ \\
\hline $\mathrm{E}_{2} \mathrm{~S}_{3}$ & 147.0 & $13.50 \mathrm{a}$ & 13.33 & $12.33 \mathrm{ab}$ & $22.56 \mathrm{a}$ & $95.85 \mathrm{a}$ & $87.05 \mathrm{a}$ & $11.17 \mathrm{ab}$ \\
\hline $\mathrm{E}_{3} \mathrm{~S}_{3}$ & 142.2 & $12.00 \mathrm{abc}$ & 12.33 & $12.33 \mathrm{ab}$ & $20.13 \mathrm{abc}$ & $80.95 \mathrm{abc}$ & $67.75 \mathrm{abc}$ & $10.53 \mathrm{~b}$ \\
\hline $\mathrm{E}_{4} \mathrm{~S}_{3}$ & 143.1 & $11.00 \mathrm{bc}$ & 12.50 & $12.00 \mathrm{ab}$ & $19.65 \mathrm{abcd}$ & $98.7 \mathrm{a}$ & $85.43 \mathrm{a}$ & $10.15 \mathrm{~b}$ \\
\hline $\mathrm{CV}_{3}(\%)$ & 8.21 & 8.94 & 22.12 & 20.23 & 8.97 & 19.68 & 19.51 & 7.48 \\
\hline $\mathrm{SE}_{2}( \pm)$ & 6.51 & 0.60 & 1.65 & 1.42 & 0.99 & 8.53 & 7.14 & 0.47 \\
\hline
\end{tabular}

Leaf area index (LAI) at 45 and 90 days after Transplanting

The ratio of total leaf area to ground cover is termed as LAI. It is typically increases to maximum after the crop emergence (Reddy, 2004). The data presented in Fig.1. revealed that micronutrients and spacing had significant effect on leaf area index at 45 and 90 DAT. The maximum LAI (0.33and 3.53) was recorded in treatment $\mathrm{E}_{4} \mathrm{~S}_{2}$ at 45 
and 90 DAT respectively. The lowest LAI was observed in solely macronutrient and closer spacing. In general, the application of Micronutrient especially boron and medium spacing had boosted up the tissue formation with better plant growth which increases its concentration in leaves and results in higher leaf area index.

\section{Crop growth rate (g $\mathrm{m}-2$ day-1)}

Crop growth rate is the dry matter production per unit time.

The data in Fig.3. revealed that combined effect of micronutrient and spacing significantly affected the crop growth rate. Micronutrients application enhanced the plant growth through increased plant photosynthesis and other physiological activities whereas, proper spacing has positive influence on nutrient uptake of plant. Among various treatments, $\mathrm{E}_{4} \mathrm{~S}_{2}$ accelerated crop growth rate $(33.78 \mathrm{~g} \mathrm{~m}-2$ day-1). The use of micronutrient and proper spacing helped the plants to better utilize the available nutrients with increased leaf area, high photosynthesis and dry matter accumulation which enhanced crop growth rate. These results satisfy the findings of Asad and Rafique (2002) who reported that boron fertilization increased the dry matter production of wheat. The minimum crop growth rate (24.43) was recorded in macronutrient application with closer spacing $\left(\mathrm{E}_{1} \mathrm{~S}_{1}\right)$.

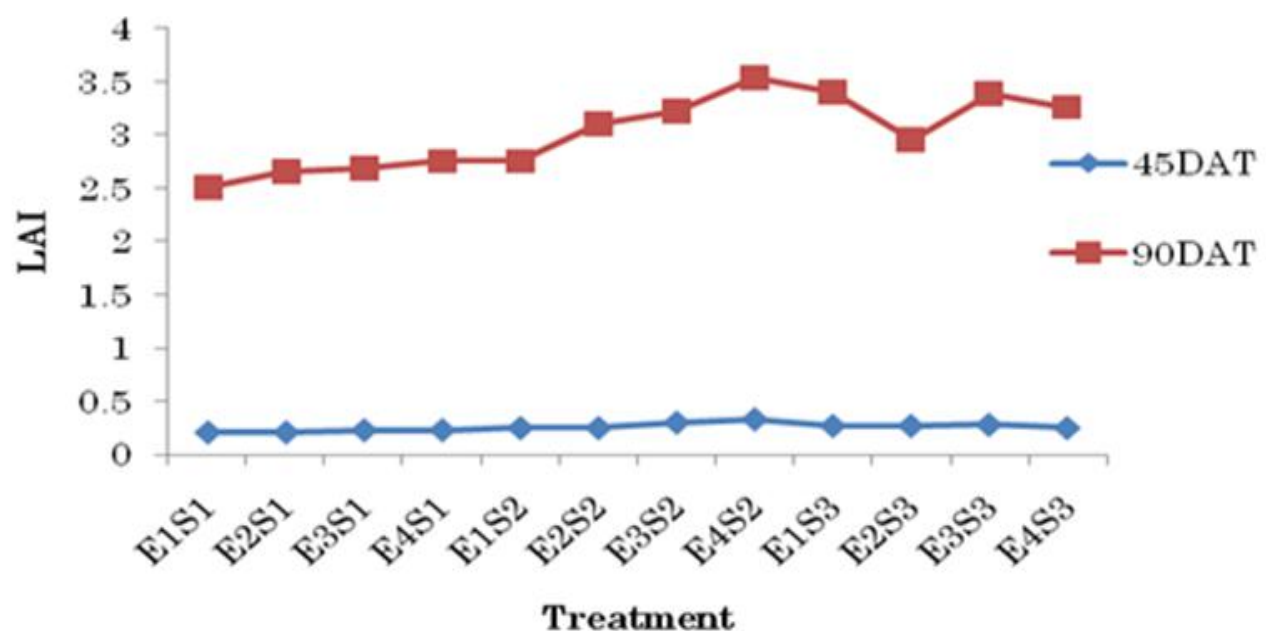

Fig. 1: Effects of different micronutrients and spacing on leafarea index of rice

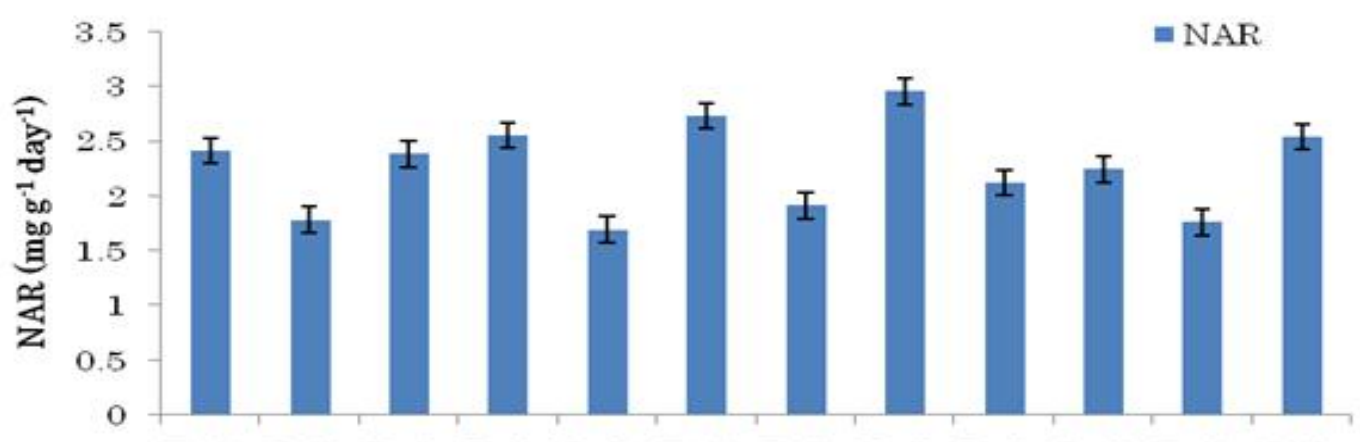

E1S1 E2S1 E3S1 E4S1 E1S2 E2S2 E3S2 E4S2 E1S3 E2S3 E3S3 E4S3

Treatment

Fig.2: Effects of different micronutrients and spacing on net assimilation rate (NAR) of rice

Relative growth rate (mg g-1 day-1)

Relative growth rate (RGR) expresses the dry weight increase in time interval in relation to the initial weight.
Since crop growth rate is an absolute measure of growth, similar values could be expected for different initial weights (Reddy, 2004). The data presented in Fig.4. revealed that 
application of different micronutrients and spacing had significant effect on the relative growth rate of rice. Maximum RGR (88.45 mg g-1 day-1) was produced in treatment $\mathrm{E}_{4} \mathrm{~S}_{2}$ which was followed by (87.58, g g-1 day-1) $\mathrm{E}_{2} \mathrm{~S}_{2}$. The reas on might be the high concentrations of boron and zinc in the leaves increased plant food accumulation which resulted in more relative growth rate (Card et al. 2005). The sole application of macronutrient $\left(E_{1} S_{2}\right)$ produced the minimum relative growth rate $\left(76.30 \mathrm{mg} \mathrm{g}^{-1}\right.$ $\left.\mathrm{day}^{-1}\right)$.
Net assimilation rate ( $\mathrm{mg} \mathbf{m}-2$ day-1)

The plant capacity to increase dry weight in terms of area of its assimilatory surface expresses the net assimilation rate. The data given in Fig. 5 revealed that different micronutrients and spacing had significant effect on net assimilation rate. Among various treatments, $\mathrm{E}_{4} \mathrm{~S}_{2}$ produced the significantly maximum net assimilation rate $(2.95 \mathrm{mg}$ $\mathrm{m}-2$ day-1) which was statistically closer with $\mathrm{E}_{2} \mathrm{~S}_{2}$ treatment. Shukla and Warsi (2000) also obtained the highest net assimilation rate with the application of $\mathrm{Zn}$ along with NPK. The minimum net assimilation rate of 1.91

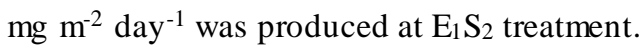

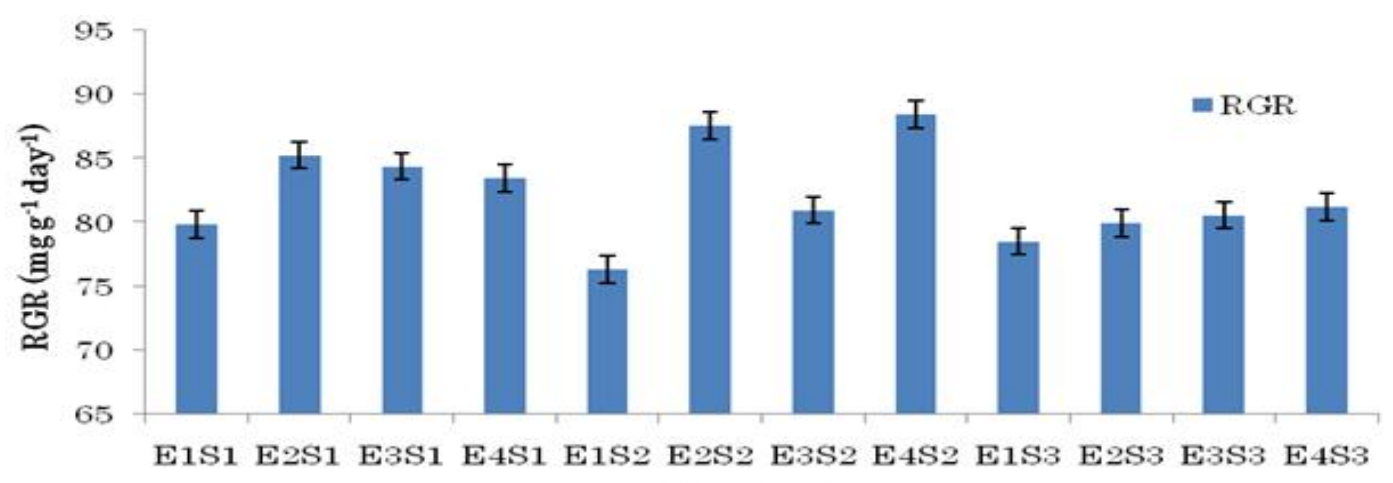

Treatment

Fig. 3: Effects of different micronutrients and spacing on relative growth rate (RGR) of rice

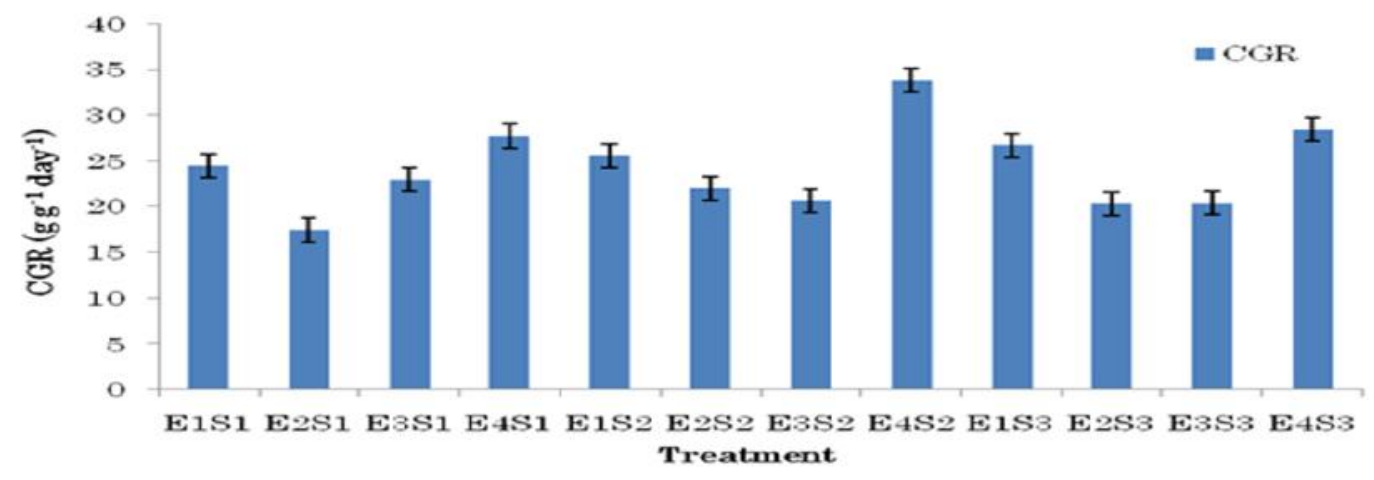

Fig.4: Effects of different micronutrients and spacing on crop growth rate (CGR) of rice

\section{Chlorophyll Content (mg/g)}

The response of growth and yield parameter depends upon the photosynthetic rate, which in turn is dependent on chlorophyll contents. In the present study, a significant increment in chlorophyll contents $(\mathrm{a}, \mathrm{b}$ and total chlorophyll) was recorded in combined effects of micronutrient and spacing along with macronutrient. The chlorophyll "a" and "b" contents was found to be correlated with each other and the treatment Zn@ @ kg ha-1, B @ 3kg ha-1, Mo@2kg ha-1 along with different macronutrients along with 20x $15 \mathrm{~cm}^{2}$ spacing $\left(\mathrm{E}_{4} \mathrm{~S}_{2}\right)$ showed highest. However, the treatment contains solely macronutrients with lowest spacing $\left(E_{1} S_{1}\right)$ showed the lowest chlorophyll content. The chlorophyll "a" and " $b$ " contents varied from 1.98 to $1.37 \mathrm{mg} \mathrm{g}-1$ and 0.69 to $0.46 \mathrm{mg}$ g-1, respectively with different combination of micronutrient and spacing. The highest chlorophyll contents ( $\mathrm{a}, \mathrm{b}$ and total) was recorded in $\left(\mathrm{E}_{4} \mathrm{~S}_{2}\right)$ treated plant. However, all other 
treatments also had increased chlorophyll contents significantly (Table 2). The chlorophyll "a", "b" and total chlorophyll contents increased up to $33.78,30.19$ and $32.34 \%$, respectively for the treatment Zn@ $@ 5 \mathrm{~kg}$ ha-1, B @ $3 \mathrm{~kg}$ ha-1 and Mo @ 2kg ha-1 along with different macronutrients along with $20 \times 15 \mathrm{~cm} 2$ spacing $\left(\mathrm{E}_{4} \mathrm{~S}_{2}\right)$ over the similar spacing control. This trend was observed because the chlorophyll contents increased considerably in $\mathrm{Zn}$ and B treated group of plants (Hatwaret al.2003).

Table.2: Effect of Micronutrient and spacing on Chlorophyll content ( $\mathrm{mg} / \mathrm{g}$ ) of rice.

\begin{tabular}{|c|c|c|c|}
\hline \multirow{2}{*}{ Treatment } & \multicolumn{3}{|c|}{ Chlorophyll Content (mg/g) } \\
\cline { 2 - 4 } & Chl. a & Chl. B & Total Chl. \\
\hline $\mathrm{E}_{1} \mathrm{~S}_{1}$ & $1.15 \mathrm{~h}$ & $0.36 \mathrm{~g}$ & $1.51 \mathrm{f}$ \\
\hline $\mathrm{E}_{2} \mathrm{~S}_{1}$ & $1.55 \mathrm{~d}$ & $0.47 \mathrm{f}$ & $2.02 \mathrm{~d}$ \\
\hline $\mathrm{E}_{3} \mathrm{~S}_{1}$ & $1.37 \mathrm{~g}$ & $0.49 \mathrm{ef}$ & $1.86 \mathrm{e}$ \\
\hline $\mathrm{E}_{4} \mathrm{~S}_{1}$ & $1.41 \mathrm{fg}$ & $0.46 \mathrm{f}$ & $1.87 \mathrm{e}$ \\
\hline $\mathrm{E}_{1} \mathrm{~S}_{2}$ & $1.48 \mathrm{e}$ & $0.53 \mathrm{de}$ & $2.01 \mathrm{~d}$ \\
\hline $\mathrm{E}_{2} \mathrm{~S}_{2}$ & $1.50 \mathrm{e}$ & $0.57 \mathrm{~cd}$ & $2.06 \mathrm{~d}$ \\
\hline $\mathrm{E}_{3} \mathrm{~S}_{2}$ & $1.63 \mathrm{c}$ & $0.56 \mathrm{~cd}$ & $2.19 \mathrm{c}$ \\
\hline $\mathrm{E}_{4} \mathrm{~S}_{2}$ & $1.98^{\mathrm{a}}$ & $0.69^{\mathrm{a}}$ & $2.66^{\mathrm{a}}$ \\
\hline $\mathrm{E}_{1} \mathrm{~S}_{3}$ & $1.40 \mathrm{fg}$ & $0.47 \mathrm{f}$ & $1.87 \mathrm{e}$ \\
\hline $\mathrm{E}_{2} \mathrm{~S}_{3}$ & $1.78 \mathrm{~b}$ & $0.64 \mathrm{ab}$ & $2.43 \mathrm{~b}$ \\
\hline $\mathrm{E}_{3} \mathrm{~S}_{3}$ & $1.78 \mathrm{~b}$ & $0.61 \mathrm{bc}$ & $2.39 \mathrm{~b}$ \\
\hline $\mathrm{E}_{4} \mathrm{~S}_{3}$ & $1.54 \mathrm{ef}$ & $0.48 \mathrm{f}$ & $2.02 \mathrm{~d}$ \\
\hline $\mathrm{CV}_{(\%}(\%)$ & 2.03 & 4.20 & 2.08 \\
\hline $\mathrm{SE}_{2}( \pm)$ & 0.02 & 0.02 & 0.03 \\
\hline
\end{tabular}

\section{CONCLUSION}

The tallest plant height $(147.0 \mathrm{~cm})$, longest root length $(13.50 \mathrm{~cm})$ and highest panicle length $(22.56 \mathrm{~cm})$ were attained in the treatment $\mathrm{E}_{2} \mathrm{~S}_{3}$, though the maximum tillers per hill (14.95) and effective panicle per hill (14.17) were obtained in the treatment $\mathrm{E}_{2} \mathrm{~S}_{2}$. Although, the maximum number of grains per panicle (98.7) was produced in the treatment combination $\mathrm{E}_{4} \mathrm{~S}_{2}$, the maximum filled grains per panicle (87.62) was observed in the treatment $\mathrm{E}_{2} \mathrm{~S}_{2}$. The maximum LAI, CGR, RGR, NAR and total chlorophyll content were produced by the $\mathrm{E}_{4} \mathrm{~S}_{2}$ treatment. Based on vegetative growth, crop growth attributes treatment combination $\mathrm{E}_{4} \mathrm{~S}_{2}$ may be specified as the best performer.

\section{REFERENCES}

[1] Alam MN, Abedin MJ, and Azad MAK. (2010). Effect of micronutrient on growth and yield of onion under calcareous soil environment. International research journal of Plant Science. 1(3):56-61.

[2] Anon. (2007). Production Year Book. An Appraisal of Seed Biology and the Yeld of Grain Crops. FAO CAB International. p.113-124.

[3] Asad A, andRafique R. (2002). Identification of micronutrient deficiency of wheat in the Peshawar valley. Commun. Soil Sci. Plant Anal. 33: 349-364

[4] Bangladesh Bureau of Statistics (BBS), (2001). Statistical Year Book of BangladeshStatistics Division, Ministry of Planning, Government of the People's Republic ofBangladesh, Dhaka.

[5] Bangladesh Bureau of Statistics (BBS), (2004). Statistical Year Book of Bangladesh.Statistics Division, Ministry of Planning, Government of the People's Republic ofBangladesh, Dhaka.

[6] Card S, Cathcart J, and Huang J. (2005). The micronutrient and trace element status of crops grown on the Alberta Soil Quality Benchmark Sites. AESA Soil Quality Monitoring Program, Alberta Agri. Food \& Rural Dev., Cons. \& Dev. Branch, pp.20.

[7] Hamid, RB, Amin F, and Reza KD. (2011). Effect of plant density onyield and yield components of rice. World Applied Sciences Journal. 12(11): 2053-2057.

[8] HamidulMDI, and Altaf SMH.(2002). Effect of fertilization and planting density on the yield of two varieties of five Rice. Pakistan Journal of Biological Sciences, 5(5): 513-516.

[9] Hatwar GP, Gondane SV, and Urkude SM. (2003). Effect of micronutrients on growth and yield of chilli. Soil Crop, 13: 123-1254. 
[10] Islam MS, Islam MZ,Rahman GKMM, and

Chowdhury MAAH.(2010). Effect of some secondary and micro nutrients along with organic amendments on T. aman. Int. J. Sustain. Crop Prod. 5(4), 51-58.

[11] Khan ZA, Khan MA, and Baloch MS. (1999). Effect of different manures on the yield of wheat. Scientific Khyber 12:41-46.

[12] Kumar A, Mishra BN,and Mishra PK. (2002). Effect of age of seedlings and plant density on growth and yield of hybrid rice. Ann. Agric Res. 23(3):381-386.

[13] Nadim MA, Awan IU, Baloch MS, Khan EA, Naveed K, and Hussain N. (2011). Effect of micronutrients on growth and yield of wheat. Pak. J. Agri. Sci., Vol. 48(3), 191-196.

[14] Rahman MT, Jahiruddin M, Humauan MR, Alam MJ, and Khan AA.(2008). Effect of Sulphur and Zinc on Growth, yield and Nutrient Uptake of Boro Rice (cv. BRRI Dhan 29). J. Soil. Nature. 2(3): 10-15

[15] Reddy SR. (2004). Principles of Crop Production Growth Regulators and Growth Analysis, 2nd Ed. Kalyani Publishers, Ludhiana, India.

[16] Rehm G, and Sims A. (2006). Micronutrients and production of hard red spring wheat. Minnes ota Crop News, Univ. Minnesota.

[17] Shukla SK, and Warsi AS. (2000). Effect of sulphur and micronutrients on growth, nutrient content and yield of wheat (TriticumaestivumL.). Indian J. Agri. Res. 34:203-205.

[18] Sohel MAT, Siddique MAB, Asaduzzaman M, Alam MN,andKarim MM. (2009). March varietal performance of transplanted amanrice under different hill densities. Bangladesh J. Agri. Res. 34(1): 33-39.

[19] Uddin MN, Islam MS, and Islam ABMS. (2008). Effect of boron on wheat at different boron application methods. J. Subtrop. Agric. Res. Dev. 6:483-486. 